\title{
Viable but nonculturable bacteria and their resuscitation: implications for cultivating uncultured marine microorganisms
}

\author{
Xiao-Hua Zhang ${ }^{1,2,4} \cdot$ Waqar Ahmad $^{1} \cdot$ Xiao-Yu Zhu $^{1} \cdot$ Jixiang Chen ${ }^{3} \cdot$ Brian Austin $^{5}$
}

Received: 23 February 2020 / Accepted: 25 March 2020 / Published online: 13 May 2020

(c) The Author(s) 2020

\begin{abstract}
Culturing has been the cornerstone of microbiology since Robert Koch first successfully cultured bacteria in the late nineteenth century. However, even today, the majority of microorganisms in the marine environment remain uncultivated. There are various explanations for the inability to culture bacteria in the laboratory, including lack of essential nutrients, osmotic support or incubation conditions, low growth rate, development of micro-colonies, and the presence of senescent or viable but nonculturable (VBNC) cells. In the marine environment, many bacteria have been associated with dormancy, as typified by the VBNC state. VBNC refers to a state where bacteria are metabolically active, but are no longer culturable on routine growth media. It is apparently a unique survival strategy that has been adopted by many microorganisms in response to harsh environmental conditions and the bacterial cells in the VBNC state may regain culturability under favorable conditions. The resuscitation of VBNC cells may well be an important way to cultivate the otherwise uncultured microorganisms in marine environments. Many resuscitation stimuli that promote the restoration of culturability have so far been identified; these include sodium pyruvate, quorum sensing autoinducers, resuscitation-promoting factors Rpfs and YeaZ, and catalase. In this review, we focus on the issues associated with bacterial culturability, the diversity of bacteria entering the VBNC state, mechanisms of induction into the VBNC state, resuscitation factors of VBNC cells and implications of VBNC resuscitation stimuli for cultivating these otherwise uncultured microorganisms. Bringing important microorganisms into culture is still important in the era of high-throughput sequencing as their ecological functions in the marine environment can often only be known through isolation and cultivation.
\end{abstract}

Keywords VBNC $\cdot$ Cultivating the uncultured $\cdot$ Resuscitation $\cdot$ Marine microorganisms

SPECIAL TOPIC: Cultivation of the uncultured microorganisms.

Edited by Chengchao Chen.

Xiao-Hua Zhang

xhzhang@ouc.edu.cn

1 College of Marine Life Sciences and Institute of Evolution \& Marine Biodiversity, Ocean University of China, Qingdao 266003, China

2 Laboratory for Marine Ecology and Environmental Science, Qingdao National Laboratory for Marine Science and Technology, Qingdao 266071, China

3 School of Petrochemical Engineering, Lanzhou University of Technology, Lanzhou 730050, China

4 Frontiers Science Center for Deep Ocean Multispheres and Earth System, Ocean University of China, Qingdao 266100, China

5 Institute of Aquaculture, University of Stirling, Stirling FK9 4LA, Scotland, UK

\section{Introduction}

Culturing has been an important feature of microbiology since the landmark work of Robert Koch in the nineteenth century. The dogma is that cultures are comprised of living bacterial cells and therefore, their presence on laboratory media is reflective of viability. However, the proviso is that these organisms need to be able to grow on the available laboratory media. Unfortunately, there is not a single medium that permits the growth of all microorganisms. Therefore, recovery of culturable bacteria reflects the availability of suitable nutrients and the adoption of appropriate incubation regimes. The inevitable outcome is that only a small proportion of marine bacteria are culturable in the laboratory. Certainly, novel techniques have been developed, such as dilution to extinction, involving the use of filtered autoclaved seawater. This approach permitted the recovery of bacteria that could grow only in oligotrophic (very low nutrient) 
media and did not initially produce visible colonies. These organisms were truly obligate oligotrophs (Schut et al. 1993). However, many taxa have never been grown on artificial media (e.g. Fehr et al. 2013), for example "Candidatus", but they may still have great importance in ecology and as the cause of disease in aquatic organisms. Multiple species of "Candidatus" have been described on the basis of DNA sequences and a few characteristics without the availability of pure cultures. For example, "Candidatus Syngnamydia venezia" has been reported as the causal agent of epitheliocystis in broad nosed pipefish (Syngnathus typhle; Fehr et al. 2013). "Candidatus Halichondribacter symbioticus" was reported as a sponge symbiont of Halichondria panicea with unknown function (Knobloch et al. 2020). Other organisms appear to cease culturability and the viable but nonculturable (VBNC) state is a typical example.

The VBNC state was first described by Xu et al. (1982), who found that an exponentially growing culture of Vibrio cholerae or Escherichia coli, subjected to incubation in a nutrient-free microcosm (e.g., sterile natural or artificial seawater free of nutrient) at low temperature $\left(4^{\circ} \mathrm{C}\right)$, exhibited a decline in culturability on conventional culture media under normal culture conditions. However, a portion of the non-culturable population remained viable when they were detected by the direct viable count (DVC) procedure developed by Kogure et al. (1979). Specifically, these VBNC cells were metabolically active and had the ability to elongate in the presence of nutrients, namely yeast extract and an inhibitor of cell division, i.e. nalidixic acid or cephalexin, but could not develop into visible colonies on conventional solid media (Fig. 1). This was the first attempt to distinguish viability from culturability, as cell viability was typically evaluated by the ability to produce visible colonies on solid media or turbidity in broth, respectively (Colwell and Grimes 2000; Pinto et al. 2015). Since then, the VBNC state has been studied extensively and demonstrated to be a unique survival strategy occurring over a wide range of Gram-negative bacteria, fewer Gram-positive bacteria, as well as some fungal species (Oliver 2010; Pinto et al. 2015). Cells enter the VBNC state in response to a variety of environmental stresses, which initiate a complex series or cascade of cellular events (Oliver 2016; Oruno et al. 2019). The bacterial cells in the VBNC state may return to a metabolically active and culturable state under appropriate circumstances (Fig. 1; Colwell and Grimes 2000; Dong et al. 2019; Pinto et al. 2015). However, care needs to be taken to ensure that apparent resuscitation does not reflect the growth of a low number of residual culturable cells that may have persisted in the environment or experimental system.

In the natural environment, microorganisms are threatened by a variety of stresses and therefore, certain strategies need to be employed that allow tolerance against conditions that are harmful to growth. The ability to enter the VBNC state is advantageous for the long-term survival of bacteria (Pinto et al. 2015), otherwise, these environmental stresses could potentially kill entire populations. These apparently dormant cells may later resuscitate when the stresses are relieved or when cells receive signals exhibiting favorable environmental conditions (Oliver 2016; Pinto et al. 2015). The survival of the fish pathogen Streptococcus parauberis was studied in seawater and sediments revealing culturability for $\sim 1$ month and $\sim 6$ months, respectively. Slightly higher survival occurred at $6{ }^{\circ} \mathrm{C}$ rather than $22^{\circ} \mathrm{C}$. During this period of culturability, metabolism declined. However, direct counts indicated that the total number of cells remained high even after culturability could not be detected. Afterwards, the addition of nutrients led to the return of culturable cells. Thus, it was reasoned that Str. parauberis could enter the VBNC state but this was reversible (Curras et al. 2002).

In this review, we focus on the issues correlated with bacterial culturability, the diversity of bacteria that enter into the VBNC state, environmental challenges that induce
Fig. 1 The life cycle of VBNC cells. VBNC refers to a physiological state where bacteria are metabolically active, but are no longer culturable on conventional growth media. It is a survival strategy adopted by many bacteria in response to harsh environmental conditions, and the VBNC cells may return to culturable state under favorable conditions

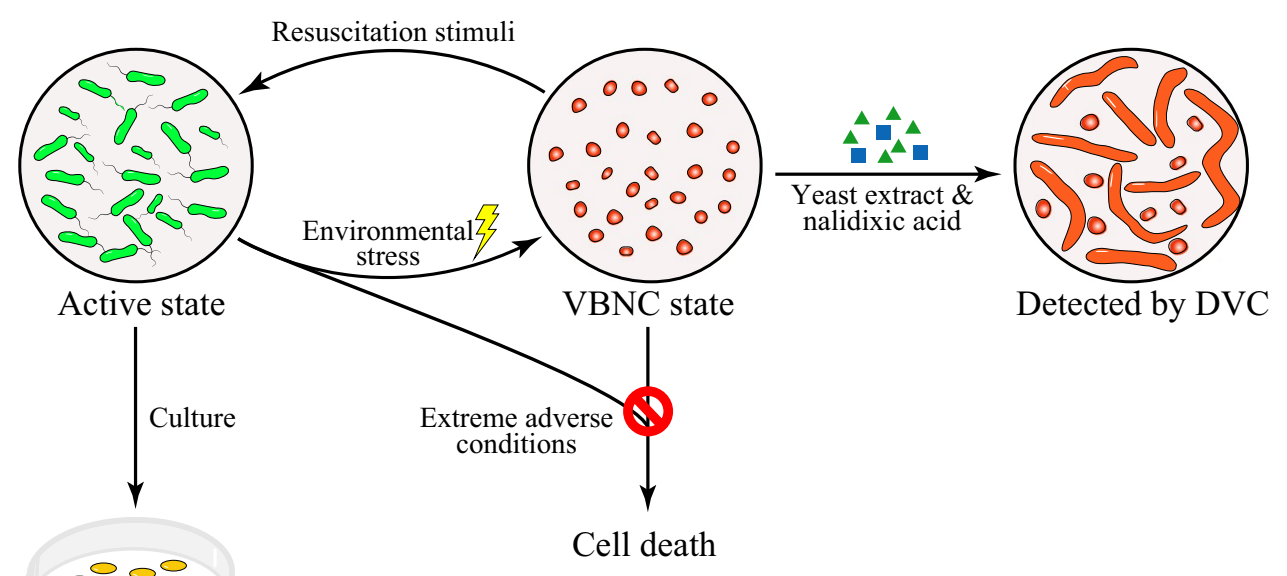


the VBNC state, conditions that help in resuscitation from the VBNC state, and the implications of resuscitation stimuli for cultivating the previously uncultured marine microorganisms.

\section{Issues associated with bacterial culturability}

There are a number of explanations for the inability to culture bacteria in the laboratory, and they are listed below:

\section{Lack or excess of essential nutrients}

For example, Renibacterium salmoninarum, which is the cause of bacterial kidney disease in salmonids, has an obligate requirement for cysteine as L-cysteine hydrochloride. Some essential nutrients may be provided by the growth of other organisms, i.e. satellitism (Austin and Austin 2016; Evelyn et al. 1989). Excessive quantities of nutrients inhibit oligotrophs, which thrive in low nutrient environments (Schut et al. 1993).

\section{Lack of appropriate osmotic support}

Osmotically-fragile cells, i.e. spheroplasts (Takayanagi et al. 2016) and L-forms, need specialized media, incorporating sucrose and horse serum, to enable the development of very small colonies, which could be buried into the surface of the media. L-forms have been reported with Aeromonas salmonicida, which is the causal agent of furunculosis and ulcer disease in fish (McIntosh and Austin 1990) and possibly Ren. salmoninarum (Hirvela-Koski et al. 2006). Moreover, seawater systems, which were found to be devoid of culturable Aer. salmonicida using conventional plating methods, contained cells that passed through the pores of $0.22 \mu \mathrm{m}$ filters, and produced colonies on a specialized L-form medium, i.e. L-F medium (Effendi and Austin 1991). It is possible that more wild strains in natural environments are sensitive to osmotic pressure.

\section{The lack of appropriate incubation conditions}

Along with appropriate media, it is essential for incubation regimes to reflect the original ecological environment from which the organisms have been recovered. Attention needs to be given to the incubation temperature [psychrophilic (Showalter and Deming 2018), mesophilic or thermophilic], duration (many organisms are slow growing, and may need several weeks to develop visible growth), atmosphere (aerobic, micro-aerophilic or anaerobic) and pressure (deep-sea bacteria will inevitably require barophilic conditions if they are to grow at all). In addition, there may be a need for an appropriate surface on which the organisms can produce biofilms.

\section{Low growth rate}

Slow-growing bacteria, such as Ren. salmoninarum, may be outcompeted on laboratory media by faster-growing aerobic heterotrophs unless active steps are taken to inhibit the unwanted organisms; this includes the use of selective isolation procedures involving disinfectants, including chlorhexidine gluconate (Nakashima et al. 2007) or antibiotics (Austin and Austin 2016). The ecological theory of " $K$-strategy" and " $r$-strategy" could also explain the competition between slow- and fast-growing bacteria; $K$-strategy slow growers have a stable existence in their habitat, $r$-strategy fast growers respond rapidly to nutrient flushing (Janssen 2009). Oligotrophic media could be used to culture the slowgrowing bacteria.

\section{Development of micro-colonies}

If culturability is akin to the development of visible colonies then limited growth leading to micro-colonies poses a dilemma for the study of VBNC. Such micro-colonies may not be seen by the naked eye (Torrella and Morita 1981) and the organism could be mistakenly thought to be uncultured. The search for micro-colonies would require the use of specialist sensitive methods, for example on-chip microscopy (Jung and Lee 2016). The reasons for the development of micro-colonies could include the exhaustion of key nutrients, the accumulation of potentially toxic metabolites or an issue with overcrowding.

\section{The existence of ultramicrobacteria}

Many bacteria, which are often the dominant component of the microbiota in the marine environment, exist as or develop into extremely small cells, which are capable of passing through the pores of $0.22 \mu \mathrm{m}$ pore size filters (Boenigk et al. 2004; Mukhanov et al. 2016; Obayashi and Suzuki 2019). These cells may be referred to as the ultramicrobacteria (Schut et al. 1993) for which culturing is not always possible. The cells may well be in a state of starvation (Fegatella and Cavicchioli 2000; Haller et al. 2000; Obayashi and Suzuki 2019) and being actively grazed by flagellates (Boenigk et al. 2004). Metabolic activity, including protease activity, has been described, indicating that the cells were viable (Obayashi and Suzuki 2019). These small cells have been linked with multiple taxa by $16 \mathrm{~S}$ rRNA gene sequencing, and include Pseudoalteromonas, Vibrionaceae representatives and Erythrobacter/Erythromicrobium/Sphingomonas (Vybiral et al. 1999). 


\section{The presence of senescent cells}

Cells which are senescent and/or damaged, may require special techniques for their recovery. For example, pre-incubation in liquid media may lead to improved culturability rather than plating directly onto solid media (Olson 1978). It is possible that the liquid medium enables the recovery and/ or repair of damaged cells, i.e. the cells need to adjust to the new environment (Rolfe et al. 2012).

\section{The presence of VBNC cells}

Some cells in the natural environment may be dormant and do not grow on laboratory media without a means of reactivation. The best studied examples of dormancy involve endospores, which are produced in some Gram-positive bacteria and are regarded as important survival structures particularly in marine sediments (Volpi et al. 2017; Wormer et al. 2019). However, in the marine environment, many Gram-negative cells have also been associated with dormancy, i.e., in the VBNC state (Kaprelyants et al. 1993; $\mathrm{Xu}$ et al. 1982). The VBNC state of bacteria is a classic example regarding the influence of bacterial physiological status on cultivation success (Roszak and Colwell 1987). Since most marine microorganisms live in oligotrophic and challenging natural environments surrounded by biological competitors, it is hypothesized that a considerable proportion of marine microbial communities may be in the VBNC state (Bodor et al. 2020). Thus, VBNC cells could constitute a huge reservoir of bacteria, which cannot be cultured easily with ordinary cultivation methods. Therefore, the resuscitation of VBNC microorganisms may act as an important means for cultivating previously uncultured (i.e. previously unsuccessfully cultivated) microorganisms.

\section{Diversity of bacteria entering the VBNC state}

After the initial description for V. cholerae and Esc. coli by Xu et al. (1982), VBNC cells were discovered among a wide range of bacteria (at least 50 genera and 101 species of bacteria; Table 1). The list includes a variety of important human pathogens, including Burkholderia pseudomallei, Campylobacter jejuni, pathogenic Esc. coli, Helicobacter pylori, Klebsiella pneumoniae, Legionella pneumophila, Listeria monocytogenes, Mycobacterium tuberculosis, Pseudomonas aeruginosa, Salmonella enterica, $V$. cholerae, and Yersinia pestis (Table 1). This list also includes many marine bacteria, including Vibrio species (i.e., V. alginolyticus, $V$. anguillarum, V. cincinnatiensis, V. fischeri, V. harveyi, $V$. parahaemolyticus and V. vulnificus) and Edwardsiella tarda (Table 1; Fig. 2). Subsequently, the VBNC state has also been found in a number of eukaryotes, most notably the yeasts Saccharomyces cerevisiae, Brettanomyces bruxellensis and Cryptococcus neoformans (Table 1).

Bacterial species reported to enter the VBNC state are phylogenetically distributed: Alphaproteobacteria (6 genera, 8 species), Betaproteobacteria (5 genera, 6 species), Gammaproteobacteria (23 genera, 53 species), Epsilonproteobacteria (4 genera, 8 species), Bacteroidetes (1 genus, 1 species), Actinobacteria (5 genera, 12 species) and Firmicutes (6 genera, 13 species) (Table 1$)$. Most of these (76 species) are Gram-negative bacteria (affiliated to the phyla Proteobacteria and Bacteroidetes), although 25 species comprised Gram-positive non-sporulating bacteria (affiliated to phyla Actinobacteria or Firmicutes). Some other Gram-positive bacteria, notably Bacillus and Clostridium species, could form endospores, which is the first reported bacterial survival state (Hutchison et al. 2014). In this connection, cysts comprise another survival state that may be observed in some Gram-negative bacteria (e.g. Azotobacter spp.).

The list of microbial species currently discovered to enter the VBNC state mainly reflects the research interest of scientists, which includes pathogen taxa (i.e., pathogens for human, plants and aquatic animals), those associated with food safety or environmental applications, rather than the actual existence of this survival process in natural microbial communities (Colwell and Grimes 2000). It may be assumed that the VBNC response is a universal process for microorganisms and may occur in a wide range of microbial taxa. Moreover, the initial concept of VBNC was narrow and based on already cultivatable microorganisms. In fact, VBNC may be a suitable term for defining the yet to be cultured microorganisms, which were viable in natural environments but non-culturable in routine growth media. Considering the vast quantity of microorganisms in the ocean, many of the uncultured microorganisms could be in the VBNC state.

\section{Physiological features and detection of the VBNC bacteria}

In the VBNC state, bacteria adopt lower growth rates and reduced levels of metabolism, e.g., there is a slowing down of the respiration rate, nutrient transport, and macromolecular synthesis. Many VBNC bacterial species decrease cell size, such as forming coccoid-shaped cells with enlarged periplasmic space (Fig. 3). The decreased surface/volume ratio may help bacteria to reduce their energy requirement (Bodor et al. 2020; Pinto et al. 2015). Often, VBNC bacteria retain their cell integrity and potential replication capabilities (Oliver 2016; Pinto et al. 2015). In addition, VBNC cells usually contain reduced concentrations of cytoplasm, total proteins and membrane fatty acids. However, VBNC cells contain relatively high ATP levels, and exhibit high 
Table 1 Bacterial and fungi species reported to enter into the VBNC state in different taxa (updated and modified from Oliver 2005, 2010 and Pinto et al. 2015)

Bacteria (50 genera, 101 species)

Proteobacteria (38 genera, 75 species)

Alphaproteobacteria (6 genera, 8 species)

Acetobacter aceti (Pinto et al. 2015)

Agrobacterium tumefaciens (Oliver 2005)

Methylocella tundrae (Misra et al. 2012)

Methylocystis hirsuta (Misra et al. 2012)

Methylocystis parvus (Misra et al. 2012)

Rhizobium leguminosarum (Oliver 2005)

Rhizobium meliloti (Oliver 2005)

Sinorhizobium meliloti (Oliver 2005)

Betaproteobacteria (5 genera, 6 species)

Acidovorax citrulli (Kan et al. 2019)

Alcaligenes eutrophus (Oliver 2005)

Burkholderia cepacia (Oliver 2005)

Burkholderia pseudomallei (Oliver 2005)

Cupriavidus metallidurans (Giagnoni et al. 2018)

Ralstonia solanacearum (Oliver 2005)

Gammaproteobacteria (23 genera, 53 species)

Acinetobacter calcoaceticus (Pinto et al. 2015)

Aeromonas hydrophila (Oliver 2010)

Aeromonas salmonicida (Oliver 2005)

Citrobacter freundii (Pinto et al. 2015)

Edwardsiella tarda (Du et al. 2007a, b)

Enterobacter aerogenes (Oliver 2005)

Enterobacter agglomerans (Pinto et al. 2015)

Enterobacter cloacae (Oliver 2005)

Erwinia amylovora (Oliver 2010)

Escherichia coli (Oliver 2005)

Francisella tularensis (Oliver 2005)

Legionella pneumophila (Oliver 2005)

Methylocaldum gracile (Misra et al. 2012)

Methylococcus capsulatus (Misra et al. 2012)

Methylomicrobium alcaliphilum (Misra et al. 2012)

Methylomonas methanica (Misra et al. 2012)

Methylosarcina fibrata (Misra et al. 2012)

Methylosinus sporium (Misra et al. 2012)

Methylosinus trichosporium (Misra et al. 2012)

Pasteurella piscicida (Oliver 2005)

Pseudomonas aeruginosa (Oliver 2005)

Pseudomonas fluorescens (Oliver 2005)

Pseudomonas putida (Oliver 2005)

Pseudomonas syringae (Oliver 2005)

Salmonella bovismorbifican (Abdallah et al. 2007)

Salmonella enterica (Oliver 2005)

Salmonella enteritidis (Oliver 2005)

Salmonella montevideo (Davies and Evison 1991)

Salmonella oranienburg (Davies and Evison 1991)

Salmonella typhi (Cho and Kim 1999)

Salmonella typhimurium (Davies and Evison 1991)

Serratia marcescens (Oliver 2005)

Shigella dysenteriae (Oliver 2005)

Shigella flexneri (Oliver 2005)

Shigella sonneii (Oliver 2005)

Vibrio alginolyticus (Oliver 2010)
Gammaproteobacteria (continued)

Vibrio anguillarum (Oliver 2005)

Vibrio campbellii (Oliver, 2005)

Vibrio cholerae (Oliver 2005)

Vibrio cincinnatiensis (Zhong et al. 2009)

Vibrio fischeri (Oliver 2005)

Vibrio harveyi (Oliver 2005)

Vibrio mimicus (Oliver 2005)

Vibrio natriegens (Oliver 2005)

Vibrio parahaemolyticus (Oliver 2005)

Vibrio proteolytica (Oliver 2005)

Vibrio salmonicida (Hoff 1989)

Vibrio vulnificus (Oliver 2005)

Xanthomonas axonopodis (Oliver 2010)

Xanthomonas campestris (Oliver 2005)

Yersinia enterocolitica (Smith et al. 1994)

Yersinia pestis (Pinto et al. 2015)

Epsilonproteobacteria (4 genera, 8 species)

Arcobacter butzleri (Pinto et al. 2015)

Campylobacter coli (Oliver 2005)

Campylobacter jejuni (Oliver 2005)

Campylobacter lari (Oliver 2005)

Helicobacter pylori (Oliver 2005)

Klebsiella aerogenes (Oliver 2005)

Klebsiella planticola (Oliver 2005)

Klebsiella pneumoniae (Oliver 2005)

Actinobacteria (5 genera, 12 species)

Arthrobacter albidus (Su et al. 2011)

Arthrobacter crystallopoietes (Ensign 1970)

Bifidobacterium animalis (Pinto et al. 2015)

Bifidobacterium lactis (Pinto et al. 2015)

Bifidobacterium longum (Pinto et al. 2015)

Micrococcus flavus (Byrd et al. 1991)

Micrococcus luteus (Kaprelyants et al. 1994)

Mycobacterium bovis (Lim et al. 1999)

Mycobacterium smegmatis (Nikitushkin et al. 2012)

Mycobacterium tuberculosis (Gample et al. 2019)

Rhodococcus biphenylivorans (Su et al. 2015)

Rhodococcus rhodochrous (Oliver 2005)

Bacteroidetes (1 genus, 1 species)

Cytophaga allerginae (Oliver 2005)

Firmicutes (6 genera, 13 species)

Enterococcus faecium (Oliver 2005)

Enterococcus faecalis (Oliver 2005)

Enterococcus hirae (Oliver 2005)

Lactobacillus brevis (Liu et al. 2018)

Lactobacillus lactis (Oliver 2005)

Lactobacillus lindneri (Pinto et al. 2015)

Lactobacillus paracollinoides (Pinto et al. 2015)

Lactobacillus plantarum (Oliver 2005)

Listeria monocytogenes (Oliver 2005)

Oenococcus oeni (Pinto et al. 2015)

Staphylococcus aureus (Pasquaroli et al. 2013)

Streptococcus faecalis (Byrd et al. 1991)

Streptococcus pyogenes (Trainor et al. 1999)

Fungi: Yeast ( 7 genera, 7 species)

Brettanomyces bruxellensis (Willenburg and Divol 2012; Capozzi et al. 2016) Rhodotorula mucilaginosa (Divol and Lonvaud-Funel 2005)

Candida stellata (Divol and Lonvaud-Funel 2005)

Saccharomyces cerevisiae (Divol and Lonvaud-Funel 2005; Salma et al. 2013)

Cryptococcus neoformans (Hommel et al. 2019)

Zygosaccharomyces bailii (Divol and Lonvaud-Funel 2005)

Dekkera bruxellensis (Barata et al. 2008) 

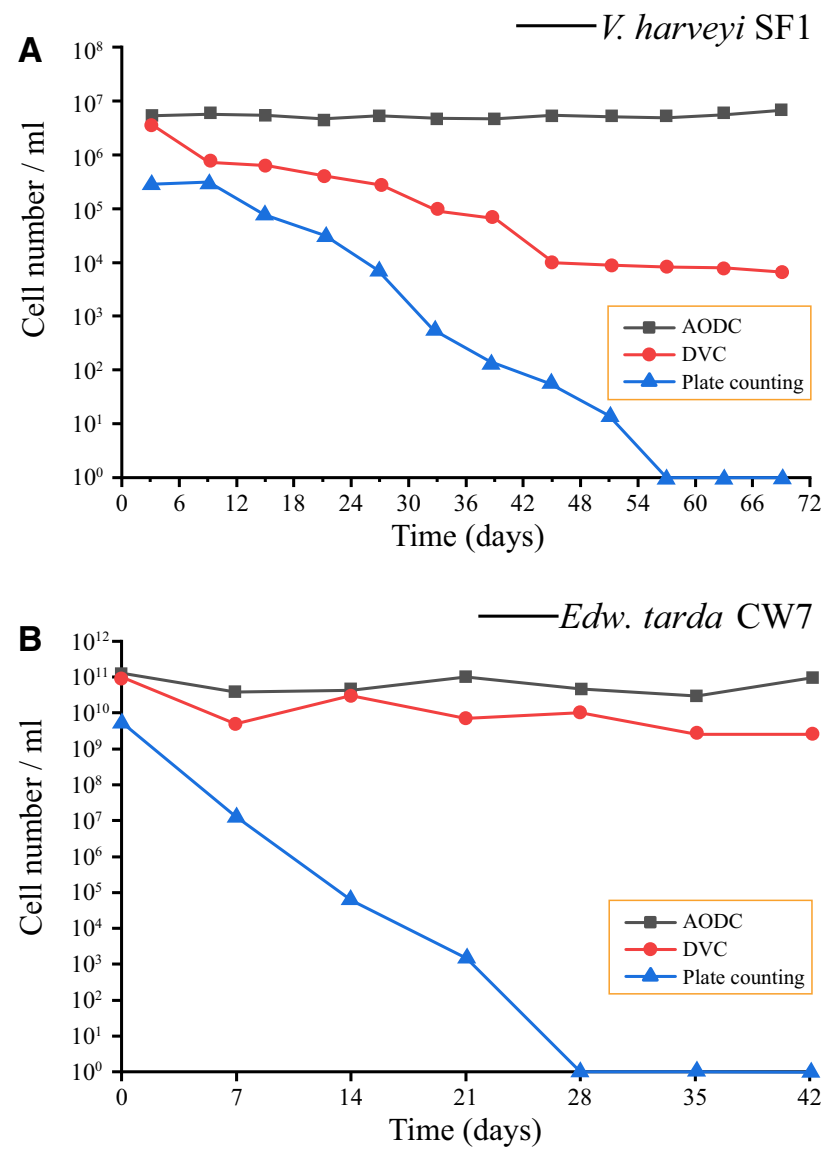

Fig. 2 Entry of Vibrio harveyi and Edwardsiella tarda into the VBNC state at $4{ }^{\circ} \mathrm{C}$ as determined by AODC, DVC and plate counting methods. a $V$. harveyi $\mathrm{SF} 1$ in a seawater microcosm (redrawn from Sun et al. 2008); b Edw. tarda CW7 in an artificial seawater microcosm (redrawn from Du et al. 2007a)

membrane potential and increased O-acetylation and crosslinking in peptidoglycan cell walls (Oliver 2016; Pinto et al. 2015). Moreover, VBNC cells show decreased superoxide dismutase activity, and increased oxidative damage. Because of these changes, VBNC cells have enhanced resistance to antibiotics and physical and chemical stresses than do culturable cells. Furthermore, the potential for virulence among VBNC pathogens is unclear. Some VBNC pathogens are unable to cause diseases until they regain culturability. Conversely, others remain potentially pathogenic as they continue expressing toxins (Dong et al. 2019).

Detection in the absence of culturing initially focused on microscopy (e.g. the DVC procedure developed by Kogure et al. 1979), the LIVE/DEAD Baclight assay (evaluating cell viability based on cytoplasmic membrane integrity, with two fluorescent stains propidium iodide and SYTO 9; Boulos et al. 1999) but has since progressed to molecular methodologies, including loop-mediated isothermal amplification (LAMP) (Cao et al. 2019; Zhong et al. 2016). Both Cao et al. (2019) and Zhong et al. (2016) compared real time
PCR (qPCR) and real time LAMP (qLAMP) in combination with propidium monoazide to detect VBNC cells of $V$. parahaemolyticus in seafood including shrimp, with the latter (in combination with propidium monoazide) being quicker and more sensitive.

\section{Mechanism of induction into the VBNC state}

Since the first report of the VBNC state, a variety of factors (e.g., physical, chemical and biotic environmental parameters) that can initiate the cascade of cellular events leading to the VBNC state have been reported. The physical factors include high/low temperature, high/low salinity (osmotic stress), sub-optimal pH, sub-optimal redox conditions, sunlight, irradiation, drying, pulsed electric field and high-pressure stress. The chemical factors include nutrient starvation, antibiotic pressure, food preservatives, disinfectants (i.e., chlorination), nitrite, heavy metals, organic pollutants or exposure to other toxic compounds (Gample et al. 2019; Oliver 2005, 2010, 2016; Pinto et al. 2015). In addition, biotic factors may also be inducers of the VBNC state. For example, the protozoan Acanthamoeba castellanii was found to induce Aer. hydrophila into the VBNC state (Rahman et al. 2008), whereas the VBNC cells of the coral pathogen, V. shiloi, were reported to be associated with a marine fire worm (Hermodice carunculata; Sussman et al. 2003). In another case, the culture supernatant of the amoeba Hartmannella vermiformis induced the VBNC state of Leg. pneumophila (Buse et al. 2013). This was considered to be caused by nutrient depletion resulting from the animal growth as well as the presence of potentially harmful metabolic products in the medium. However, the environmental stresses inducing the VBNC state seem to vary between studies (Pinto et al. 2015). One possible explanation may be that the culture conditions investigated were always complicated, with several possible stresses interacting with each other. Many stresses, such as sub-optimal temperature, nutrient, salinity, $\mathrm{pH}$, dissolved oxygen, and irradiation, may affect the viable process and lead to the VBNC state of the cells.

Since the first report of VBNC, many studies have focused on explaining the mechanism of VBNC formation (Oliver 2016; Pinto et al. 2015). However, there is still very little information on the genetic mechanisms behind the VBNC process (Trevors 2011). The environmental stresses that can induce the VBNC state may give clues to the underlying genetic regulation of VBNC cells.

One explanation of VBNC formation is that when actively growing microorganisms face a sudden shock, such as shortage of nutrients, change of $\mathrm{pH}$, or the presence of harmful metabolites, it leads to the decoupling of growth from metabolism. Consequently, cells may suffer a 

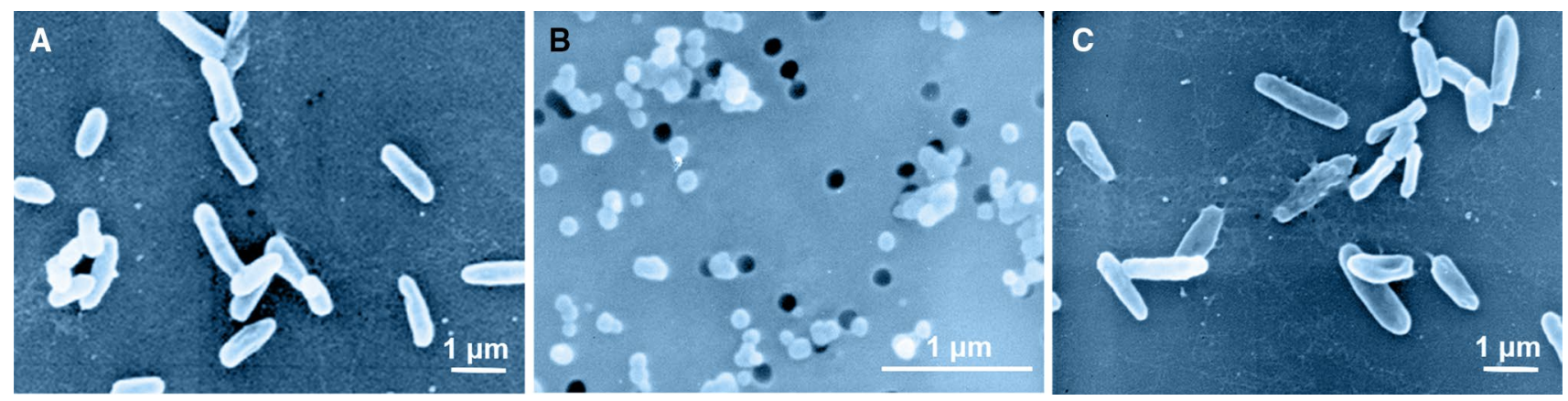

Fig. 3 Morphological characteristics of Vibrio harveyi SF1 analyzed with a scanning electron microscope. a Normal cells; b VBNC cells; c Resuscitated cells

burst of oxidative metabolism, which will accumulate peroxides and other free radicals within cells (Munn 2020). Microorganisms may avoid this occurrence if they are induced to make changes to protect the DNA, proteins, and other essential components in the cells. The shock of the sudden transfer of cells into a rich medium when they are still in the process of adaptation to life in the oligotrophic aquatic environment could otherwise result in sudden death (Munn 2020). The inability of VBNC cells to detoxify lethal free radicals either induced by the cells themselves or present in culture medium is one of the main reasons for the non-culturability. This process may be due to the repression of periplasmic catalase, which breaks down toxic peroxide (Munn 2020). As a result, several proteins have been shown to play a significant role in the formation of VBNC cells; these include superoxide dismutase (SodA), catalases KatA and KatG, RNA polymerase sigma $\mathrm{S}$ (RpoS), alkyl hydroperoxide reductase subunit C (AhpC), sensory histidine kinase (EnvZ), and a LysRtype transcriptional regulator (OxyR) (Dong et al. 2019).

\section{The resuscitation factors of VBNC cells}

Despite VBNC cells typically having low levels of metabolic activity, through specific treatments, many cells are able to revert to a metabolically active and culturable state when cultured on conventional bacteriological media. The process of VBNC cells recovering to culturability is termed resuscitation (Colwell and Grimes 2000; Oliver 2010). Since the VBNC state is triggered by the environmental stresses mentioned above, eliminating these stresses may help reversion to culturability. Nevertheless, the resuscitation of some species through simply reversing the adverse stress is not always successful. It should be noted that the diversity of VBNC bacteria (50 genera, 101 species) is much higher than that of resuscitation (less than 20 species), mostly due to the lack of knowledge on the underlying mechanisms of this process. However, many conditions that promote the restoration of culturability have been identified, including physical stimuli (e.g., upshifting of temperature), chemical stimuli (e.g., pyruvate, glutamate, amino acids, Tween 20, vitamins, metal chelating agents or siderophore, and quorum sensing signal molecules), active proteins (e.g., Rpfs, YeaZ and catalase), or host associated stimuli (Table 2). The resuscitation process differs among different bacterial taxa, and may be initiated by several stimuli. The specific conditions that help in resuscitation from the VBNC state are described in more detail below.

\section{Physical stimuli}

The most common factor inducing the VBNC state for bacteria (e.g., Vibrio species and many other genera) is low temperature (Colwell and Grimes 2000; Oliver 2010). Many studies have shown that a temperature upshift is sufficient to allow resuscitation from the VBNC state induced by the low temperature (e.g., Du et al. 2007a, b; Gupte et al. 2003; Pinto et al. 2015; Wong et al. 2004). In this regard, climate change may well be accelerating Vibrio resuscitation rates (Oliver 2016). In addition, temperature upshift in the presence of chemical stimuli, such as yeast extract, Tween 20, vitamin B or catalase, were also useful in resuscitating VBNC cells (e.g., Du et al. 2007a, b; Sun et al. 2008; Zhong et al. 2009).

\section{Chemical stimuli}

Sodium pyruvate has been reported as one of the principal promoters of resuscitating VBNC cells, with its function as a reactive oxygen scavenger, or so-called antioxidant, as well as a carbon source (Ducret et al. 2014; Vilhena et al. 2019). Sodium pyruvate can restore the biosynthesis of DNA, proteins and other macromolecules, thus resuscitating VBNC 
Table 2 Resuscitation promoting factors for VBNC cells

Resuscitation promoting factors

Bacterial species tested (References)

\section{Physical stimuli}

Temperature upshift

Aeromonas hydrophila (Maalej et al. 2004)

Escherichia coli (Pinto et al. 2011)

Vibrio parahaemolyticus (Wong et al. 2004)

V. vulnificus (Oliver et al. 1995)

V. alginolyticus (Du et al. 2007b)

Temperature upshift in the presence of yeast extract, Tween 20, vitamin B or catalase

Edwardsiella tarda (Du et al. 2007a)

V. alginolyticus (Du et al. 2007b)

V. cincinnatiensis (Zhong et al. 2009)

V. harveyi (Sun et al. 2008)

Heat shock in rich culture media

Salmonella enterica (Gupte et al. 2003)

\section{Chemical stimuli}

Sodium pyruvate

Glutamate

Gluconate

Amino acids

Rich culture media

Vitamins

Tween 20

Gas mixture

Chelator

Siderophore

Quorum sensing molecules

\section{Active proteins}

Resuscitation promoting factor Rpf

Resuscitation promoting factor like protein YeaZ

Catalase

\section{Host associated stimuli}

Protozoan

Rabbit ileal loop

Mouse model

Embryonated egg model

Salmonella enteritidis (Morishige et al. 2013)

Legionella pneumophila (Ducret et al. 2014)

Leg. pneumophila (Ducret et al. 2014)

Cupriavidus metallidurans (Giagnoni et al. 2018)

Esc. coli (Pinto et al. 2011)

Arcobacter butzleri (Fera et al. 2008)

Enterococcus faecalis (Lleo et al. 1998, 2001)

Enterococcus hirae (Lleo et al. 2001)

Esc. coli (Ozkanca et al. 2009; Pinto et al. 2011)

V. cincinnatiensis (Zhong et al. 2009)

V. harveyi (Sun et al. 2008)

Sal. enterica (Zeng et al. 2013)

Campylobacter jejuni (Bovill and Mackey 1997)

Pseudomonas aeruginosa (Dwidjosiswojo et al. 2011)

Esc. coli (Lewis et al. 2010)

Micrococcus luteus (Lewis et al. 2010)

Esc. coli (Liu et al. 2009)

V. vulnificus (Ayrapetyan et al. 2014)

Mic. luteus (Mukamolova et al. 2002)

Sal. enterica (Panutdaporn et al. 2006)

V. parahaemolyticus (Aydin et al. 2011a, b)

V. harveyi (Li et al. 2017)

Esc. coli (Gourmelon et al. 1994)

Sal. enterica (Zeng et al. 2013)

Leg. pneumophila (Garcia et al. 2007; Steinert et al. 1997)

V. cholerae (Colwell et al. 1985)

Vibrio vulnificus (Oliver and Bockian 1995)

Cam. jejuni (Cappelier et al. 1999)

Edw. tarda (Du et al. 2007a)

Listeria monocytogenes (Guillou et al. 2008)

Cam. jejuni (Cappelier et al. 2007) 
cells to a culturable state (Morishige et al. 2013; Vilhena et al. 2019). The VBNC cells of the human pathogen Leg. pneumophila could be resuscitated in culture media with other reactive oxygen scavengers, such as glutamate (Ducret et al. 2014). Also, gluconate could induce the resuscitation of the soil-borne organism Cupriavidus metallidurans from the VBNC state to a cultural state (Giagnoni et al. 2018).

Combinations of a variety of amino acids, such as asparagine, glutamine, methionine, serine and threonine, in the basal minimal medium were shown to effectively support the transition of Esc. coli VBNC cells (Pinto et al. 2011). Rich culture media and vitamins may resuscitate cells of many bacterial species from the VBNC state (Fera et al. 2008; Lleo et al. 1998, 2001; Ozkanca et al. 2009; Pinto et al. 2011; Sun et al. 2008; Zhong et al. 2009). However, the exact substance in rich culture media that is vital to the resuscitation process remains unclear.

The addition of 3\% $(v / v)$ Tween 20 allowed the VBNC coccoid cells of Sal. enterica serovar Typhi to regain culturability, again within $24-48 \mathrm{~h}$, and the resuscitated cells remained virulent as evidenced by animal infectivity experiments (Zeng et al. 2013). Moreover, the dormancy of the Cam. jejuni VBNC cells, caused by low oxygen availability, could be restored in the presence of a microaerobic gas mixture (Bovill and Mackey 1997). The dormancy of Pse. aeruginosa $\mathrm{VBNC}$ cells, caused by the presence of toxic concentrations of copper ions, could be resuscitated by the addition of the copper-ion chelator diethyldithiocarbamate. Then, the resuscitated cells showed cytotoxicity to the eukaryotic Chinese Hamster Ovary cell line (Dwidjosiswojo et al. 2011). Siderophores promote cell division. Furthermore, Lewis et al. (2010) showed that the siderophores from Esc. coli and Micrococcus luteus could be used as growth factors for uncultured bacterial strains.

Quorum sensing (QS) signal molecules have been reported to correlate with the resuscitation of cells from the VBNC state (Ayrapetyan et al. 2014; Liu et al. 2009), probably correlated with the ability to increase antioxidative capacity (Mesrop et al. 2014). QS is a cell-to-cell communication system in bacteria that works through the production, release, detection and group-level response to signaling molecules, called autoinducers (Papenfort and Bassler 2016). Esc. coli O157:H7 was reported to be resuscitated by the autoinducer 2 (A1-2) that was produced during biofilm formation process in a serum-based medium (Liu et al. 2009). In addition, A1-2 could reverse the VBNC state in V. vulnificus (Ayrapetyan et al. 2014). Furthermore, it has been reported that QS could trigger catalase expression leading to resuscitation of Salmonella typhimurium VBNC cells independent of the OxyR regulon (Liao et al. 2019). These phenomena suggest that QS exerts an important role in the resuscitation process.

\section{Active proteins}

In Gram-positive bacteria, a group of extracellular bacterial proteins, known as resuscitation-promoting factors (Rpfs), were shown to have an important role in promoting resuscitation of VBNC cells (Mukamolova et al. 1998, 2002; Pinto et al. 2015). Rpfs have been reported in a variety of Grampositive bacteria, including Mic. luteus, Corynebacterium spp., Lis. monocytogenes, Mycobacterium spp., Streptomyces spp., Tomitella biformata and Sal. enterica serovar Typhimurium (Pinto et al. 2015). The Rpfs from different bacterial species may have different structures and activities but all share a conserved domain of $\sim 70$ amino acids and possess a lysozyme-like activity (e.g., peptidoglycan lytic or muralytic activity). The mechanism of Rpfs on resuscitating VBNC cells probably centers on the ability to cleave cell wall compositions, thereby discharging the lysis products. These may function as signaling molecules for growth initiation or modifying the mechanical properties of the cell wall to enable cell division (Kana and Mizrahi 2010; Keep et al. 2006).

In Gram-negative bacteria, the resuscitation-promoting like factors belong to an obviously different protein class, named YeaZ, which allows cells to survive in and exit from the VBNC state. Panutdaporn et al. (2006) reported that YeaZ from Sal. typhimurium could promote resuscitation of VBNC cells of Sal. enterica serovar Oranienburg. In addition, the expression of a YeaZ homologue was essential for the survival of Esc. coli cells (Handford et al. 2009). Furthermore, YeaZ of V. parahaemolyticus acted as a classic actin-like nucleotide-binding protein, and exerted an important role in reverting the $V$. parahaemolyticus VBNC cells (Aydin et al. 2011a, b). However, the underlying molecular mechanism of YeaZ in the resuscitation of VBNC cells remains unknown.

Catalase is the hydrogen peroxide degradation protein that may promote resuscitation of the VBNC state of Esc. coli as induced by phototoxicity of visible light (Gourmelon et al. 1994). Catalase is effective in reducing phototoxicity by eliminating hydrogen peroxide, thiourea, a hydroxyl radical scavenger and desferrioxamine $\mathrm{B}$. The addition of $1 \%(v / v)$ catalase allowed the VBNC cells of Sal. enterica to return to culturability (Zeng et al. 2013).

\section{Host associated stimuli}

A variety of animal models (especially the natural host) may be biological mediators for the resuscitation of some bacteria from the VBNC state. For example, the VBNC cells of Leg. pneumophila has been reported to be resuscitated in the protozoa Acanthamoeba polyphaga (Garcia et al. 2007) and Acanthamoeba castellanii (Steinert et al. 1997). VBNC cells of $V$. cholerae were resuscitated 
to pathogenicity and culturability by their introduction in a rabbit ileal loop model, which was the first animal model to resuscitate VBNC cells (Colwell et al. 1985). The original "four segment ligation of the intestine" rabbit ileal loop model (Fig. 4a) was further modified to "double segment ligation of the intestine" model (Fig. 4b) by Huai-Shu Xu (late; who reported the VBNC state in 1982 for the first time) and Weishang Ji from the Ocean University of China. VBNC cells of $V$. cholerae could also be resuscitated in the intestines of human volunteers (Colwell et al. 1996). In addition, Cam. jejuni was resuscitated by the inoculation of VBNC cells into mice (Cappelier et al. 1999). Moreover, the embryonated egg model (Fig. 4c) was successfully used in the resuscitation of bacterial pathogens, Lis. monocytogenes, Edw. tarda and Cam. jejuni from the VBNC state (Cappelier et al. 2007; Du et al. 2007a; Guillou et al. 2008), and this model was more convenient to use than other animal models.

\section{Implications of VBNC resuscitation stimuli for cultivating uncultured marine microorganisms}

The application of molecular biology techniques, especially 16S rRNA gene and metagenomic sequencing, has revolutionized knowledge of bacterial and archaeal diversity in the oceans. This knowledge has helped us to recognize and relate groups of organisms based solely on their genetic sequences. It is well established that less than $1 \%$ of the potentially $10^{11}-10^{12}$ microbial species in the natural environment may be grown on laboratory culture media (Hahn et al. 2019; Locey and Lennon 2016); the vast majority of the microorganisms are viable in the environment but they usually do not form visible colonies on agar plates (Kogure et al. 1979; Rappe and Giovannoni 2003). This problem has been described as "The Great Plate Count Anomaly". Many major divisions of Bacteria and Archaea contain no known cultured species (Castelle and Banfifield 2018). This means that some bacterial and archaeal phyla are known only from sequence data of environmental DNA, and we do not have the cultures of many widely distributed marine phyla.

Laboratory cultures are still immensely beneficial in the era of molecular biology and high-throughput sequencing. Microbial cultures enable detailed studies of cell physiology, genetics and evolutionary relationships, knowing the morphology of the microorganisms, isolation of bacteriophages, and discovery of novel metabolic pathways. It is not always possible to predict the activity of microorganisms and their ecosystem function from genome sequence alone. Having laboratory cultures is essential to understand communitylevel processes and answering important questions regarding the role of microorganisms in the sea. In addition, metagenomic analysis of microbial communities relies heavily on data obtained from the sequencing of genomes of cultivated species (Carini 2019). Moreover, laboratory cultures are also important for commercially important research, such as screening of natural products. Clearly, cultivation-dependent and cultivation-independent approaches are complementary to the microbial community studies. For the future, it is important to develop new cultivation strategies.

In recent years, some resuscitation stimuli have been used successfully to recover bacteria from natural environments. Rpf protein (Mukamolova et al. 1998, 2002) is one of the

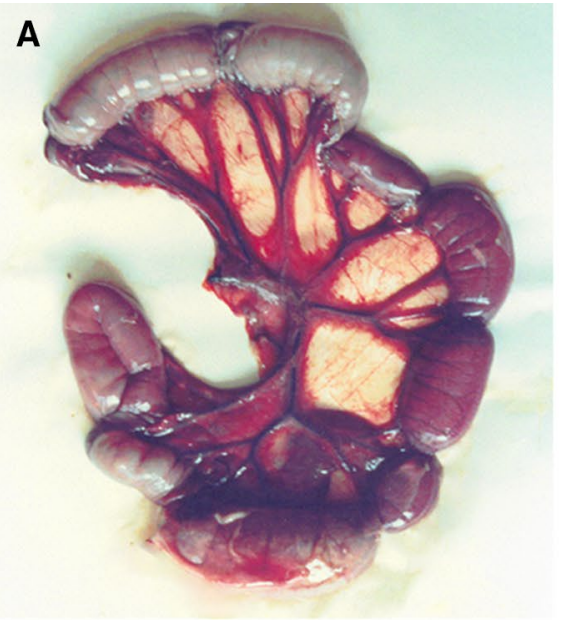

B

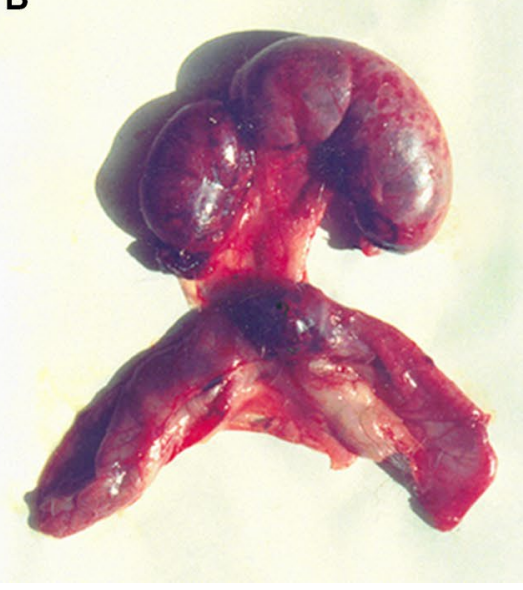

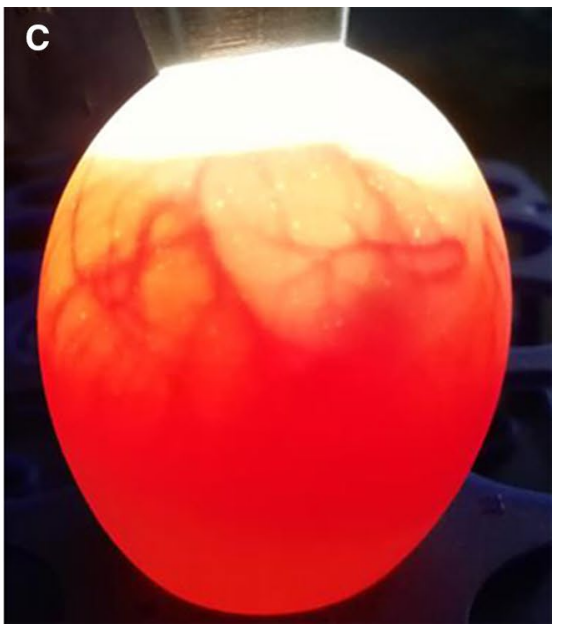

Fig. 4 Rabbit ileal loop models and embryonated egg model for resuscitation of the VBNC state. a The conventional "four segment ligation of the intestine" rabbit ileal loop model (the rabbit survived for 18-22 h) provided by Huai-Shu Xu (late) and Weishang Ji from
Ocean University of China; b The improved "double segment ligation of the intestine" rabbit ileal loop model (the rabbit survived for 24-36 h) developed by Huai-Shu Xu and Weishang Ji; c Embryonated egg model of seven days old 
most powerful resuscitation stimuli, and a picomole-level concentration could promote the growth of culturable cells by more than 100 times (Su et al. 2013). Ding and Yokota (2010) reported that the addition of a Rpf-containing culture supernatant from Mic. luteus could promote the growth of Curvibacter fontanus (validation name in Int J Syst Evol Microbiol, 2010, 60:2509-2510); a micro-aerobic organism isolated from well water in Japan. Subsequently, the addition of Rpf-containing culture supernatant from Mic. luteus enhanced the isolation of the biphenyl-degrading bacteria from PCB-contaminated soils of e-waste recycling sites in Taizhou, China (Su et al. 2013).

Beside the application of Rpf-containing culture supernatant, the use of recombinant Rpf protein has attracted attention. For example, Ding et al. (2012) demonstrated that the recombinant $\mathrm{Rpf}$ protein from Mic. luteus had a strong ability to promote the resuscitation of VBNC cells of a high-G + C Gram-positive Rhodococcus sp. DS471, which was isolated from soil. Moreover, the introduction of recombinant Rpf protein from Mic. luteus enabled the isolation of some unique bacterial species, which belonged to the genera Arthrobacter, Bacillus, Bordetella, Mycobacterium, Nocardiopsis, Novosphingobium and Pandoraea. Also, Rpf treatment significantly enhanced cellulase activity of the microbial community in mature compost produced from household and agro-industrial wastes in China ( $\mathrm{Su}$ et al. 2018). Furthermore, Luo et al. (2019) overexpressed and purified the recombinant Rpf protein from an oil-degrading organism, Rhodococcus erythropolis, and showed that Rpf could promote the resuscitation of the VBNC cells of Rho. erythropolis as well as efficiently improve the growth of normal Rho. erythropolis culture.

Sodium pyruvate was used successfully as a resuscitation stimulus, leading to the recovery of bacteria from natural environments. In this connection, Mu et al. (2018) developed an enrichment culture with a low-nutrient medium containing $10 \mathrm{mmol} / \mathrm{L}$ sodium pyruvate for efficiently isolating and culturing previously uncultured bacteria from coastal sediment of China. The work led to the isolation of 97 potentially novel taxa, including one order, one family, 16 genera and 79 species. In addition, it is very common to facilitate the isolation of novel archaeal species by supplementation of sodium pyruvate in the culture medium (Han et al. 2019). Certainly, more chemical stimuli should be applied to recover uncultured bacteria from natural environments in future studies.

\section{Conclusions}

Marine microorganisms exist in an ever-challenging environment, and only a small proportion may be cultivated using currently available techniques. There are a variety of explanations for the inability to culture bacteria in the laboratory, including the use of unsuitable cultivation methods, neglected slow-growing microorganisms, the inability to communicate among microbial cells in pure culture, cell damage induced by oxidative stress of fast-growing bacteria, and the existence of VBNC bacteria. Many Gram-negative bacteria and nonsporulating Gram-positive bacteria can enter the VBNC state, which is a complicated metabolic strategy of bacteria to survive for long-term under adverse conditions. It is assumed that the VBNC response of bacteria is a common process, which may occur in the wider scope of bacterial taxa. In this regard, VBNC cells could constitute a huge reservoir of natural bacteria, which cannot be cultured easily with ordinary cultivation methods. Various resuscitating stimuli, which are able to revert VBNC cells to a metabolically active and culturable state on conventional bacteriological media, have been identified, including physical and chemical stimuli, active proteins, and biological stimuli. However, most studies of VBNC bacteria have focused on pure cultures in the laboratory rather than on environmental bacteria. Stimuli that are currently used on model or indicator strains may well be used to recover cells from the VBNC state in natural environments. Indeed, some resuscitation stimuli have recently been used successfully to recover bacteria from natural environments. Resuscitating indigenous microorganisms from environments may provide a new approach to explore crucial populations, which may play key roles in ecological processes or have great value for industrial applications, and deserve more attention and effort. In addition, different bacterial taxa may adopt different ways to resuscitate, and this point warrants further investigation.

Acknowledgements The work was supported by National Key Research and Development Program of China (No. 2018YFE0124100), National Natural Science Foundation of China (Nos. 41730530 and 91751202) and Marine S \& T Fund of Shandong Province for Pilot National Laboratory for Marine Science and Technology (Qingdao) (No. 2018SDKJ0406-4).

Author contributions $\mathrm{X}-\mathrm{HZ}$ conceived the idea to this work and wrote the manuscript. X-YZ and CJ prepared the figures. BA and WA wrote the manuscript. All authors edited and approved the final manuscript.

\section{Compliance with ethical standards}

Conflict of interest The authors declare that they have no conflict of interest.

Animal and human rights statement This article does not contain any studies with human participants or animals performed by the authors.

Open Access This article is licensed under a Creative Commons Attribution 4.0 International License, which permits use, sharing, adaptation, distribution and reproduction in any medium or format, as long as you give appropriate credit to the original author(s) and the source, 
provide a link to the Creative Commons licence, and indicate if changes were made. The images or other third party material in this article are included in the article's Creative Commons licence, unless indicated otherwise in a credit line to the material. If material is not included in the article's Creative Commons licence and your intended use is not permitted by statutory regulation or exceeds the permitted use, you will need to obtain permission directly from the copyright holder. To view a copy of this licence, visit http://creativecommons.org/licenses/by/4.0/.

\section{References}

Abdallah FB, Lagha R, Bakhrouf A (2007) Resuscitation and morphological alterations of Salmonella bovismorbificans cells under starvation in soil. World J Microbiol Biotechnol 24:1507-1512

Austin B, Austin DA (2016) Bacterial fish pathogens: disease of farmed and wild fish, 6th edn. 3. Aerobic Gram positive rods and cocci Aerobic Gram-positive rods and cocci. Springer, Dordrecht, pp 83-160

Aydin I, Dimitropoulos A, Chen SH, Thomas C, Roujeinikova A (2011a) Purification, crystallization and preliminary X-ray crystallographic analysis of the putative Vibrio parahaemolyticus resuscitation-promoting factor YeaZ. Acta Crystallogr Sect F Struct Biol Cryst Commun 67:604-607

Aydin I, Saijo-Hamano Y, Namba K, Thomas C, Roujeinikova A (2011b) Structural analysis of the essential resuscitation promoting factor YeaZ suggests a mechanism of nucleotide regulation through dimer reorganization. PLoS ONE 6:e23245

Ayrapetyan M, Williams TC, Oliver JD (2014) Interspecific quorum sensing mediates the resuscitation of viable but non-culturable vibrios. Appl Environ Microbiol 80:2478-2483

Barata A, Caldeira J, Botelheiro R, Pagliara D, Malfeito-Ferreira M, Loureiro V (2008) Survival patterns of Dekkera bruxellensis in wines and inhibitory effect of sulphur dioxide. Int J Food Microbiol 121:201-207

Bodor A, Bounedjoum N, Vincze GE, Kis AE, Laczi K, Bende G, Szilagyi A, Kovacs T, Perei K, Rakhely G (2020) Challenges of unculturable bacteria: environmental perspectives. Rev Environ Sci Biotechnol 19:1-22

Boenigk J, Stadler P, Wiedlroither A, Hahn MW (2004) Strain-specific differences in the grazing sensitivities of closely related ultramicrobacteria affiliated with the Polynucleobacter cluster. Appl Environ Microbiol 70:5787-5793

Boulos L, Prevost M, Barbeau B, Coallier J, Desjardins R (1999) LIVE/ DEADBacLight: application of a new rapid staining method for direct enumeration of viable and total bacteria in drinking water. J Microbiol Meth 37:77-86

Bovill RA, Mackey BM (1997) Resuscitation of 'non-culturable' cells from aged cultures of Campylobacter jejuni. Microbiology 143:1575-1581

Buse HY, Donohue MJ, Ashbolt NJ (2013) Hartmannella vermiformis inhibition of Legionella pneumophila cultivability. Microb Ecol 66:715-726

Byrd JJ, Xu H-S, Colwell RR (1991) Viable but nonculturable bacteria in drinking water. Appl Environ Microbiol 57:875-878

Cao X, Zhao LC, Zhang JF, Chen X, Shi L, Fang X, Xie H, Chang YL, Wang L (2019) Detection of viable but nonculturable Vibrio parahaemolyticus in shrimp samples using improved real-time PCR and real-time LAMP methods. Food Control 103:145-152

Capozzi V, Di Toro MR, Grieco F, Michelotti V, Salma M, Lamontanara A, Russo P, Orru L, Alexandre H, Spano G (2016) Viable But Not Culturable (VBNC) state of Brettanomyces bruxellensis in wine: new insights on molecular basis of VBNC behaviour using a transcriptomic approach. Food Microbiol 59:196-204
Cappelier JM, Magras C, Jouve JL, Federighi M (1999) Recovery of viable but non-culturable Campylobacter jejuni cells in two animal models. Food Microbiol 16:375-383

Cappelier JM, Besnard V, Roche SM, Velge P, Federighi M (2007) Avirulent viable but nonculturable cells of Listeria monocytogenes need the presence of an embryo to be recovered in egg yolk and regain virulence after recovery. Vet Res 38:573-583

Carini P (2019) A “cultural" renaissance: genomics breathes new life into an old craft. mSystems 4:e00092-19

Castelle CJ, Banfifield JF (2018) Major new microbial groups expand diversity and alter our understanding of the tree of life. Cell 172:1181-1197

Cho JC, Kim SJ (1999) Green fluorescent protein-based direct viable count to verify a viable but non-culturable state of Salmonella typhi in environmental samples. J Microbiol Meth 36:227-235

Colwell RR, Grimes DJ (2000) Nonculturable microorganisms in the environment. ASM Press, Washington

Colwell RR, Brayton PR, Grimes DJ, Roszak DB, Huq SA, Palmer LM (1985) Viable but non-culturable Vibrio cholerae and related pathogens in the environment: implications for release of genetically engineered microorganisms. Nat Biotechnol 3:817-820

Colwell RR, Brayton P, Herrington D, Tall B, Huq A, Levine MM (1996) Viable but non-culturable Vibrio cholerae O1 revert to a cultivable state in the human intestine. World J Microbiol Biotechnol 12:28-31

Curras M, Magarinos B, Toranzo AE, Romalde JL (2002) Dormancy as a survival strategy of the fish pathogen Streptococcus parauberis in the marine environment. Dis Aquat Org 52:129-136

Davies CM, Evison LM (1991) Sunlight and the survival of enteric bacteria in natural waters. J Appl Bacteriol 70:265-274

Ding L, Yokota A (2010) Curvibacter fontana sp. nov. a microaerobic bacteria isolated from well water. J Gen Appl Microbiol 56:267-271

Ding L, Zhang P, Hong H, Lin H, Yokota A (2012) Cloning and expression of Micrococcus luteus IAM $14879 \mathrm{Rpf}$ and its role in the recovery of the VBNC state in Rhodococcus sp. DS471. J Microbiol 52:77-82

Divol B, Lonvaud-Funel A (2005) Evidence for viable but nonculturable yeasts in botrytis affected wine. J Appl Microbiol 99:85-93

Dong K, Pan H, Yang D, Rao L, Zhao L, Wang Y, Liao Y (2020) Induction, detection, formation, and resuscitation of viable but non-culturable state microorganisms. Compr Rev Food Sci Food Saf 19:149-183

Du M, Chen J, Zhang X-H, Li A, Li Y, Wang Y (2007a) Retention of virulence in a viable-but-nonculturable Edwardsiella tarda isolate. Appl Environ Microbiol 73:1349-1354

Du M, Chen J, Zhang X-H, Li A, Li Y (2007b) Characterization and resuscitation of viable but nonculturable Vibrio alginolyticus 283. Arch Microbiol 188:283-288

Ducret A, Chabalier M, Dukan S (2014) Characterization and resuscitation of 'non-culturable' cells of Legionella pneumophila. BMC Microbiol 14:3

Dwidjosiswojo Z, Richard J, Moritz MM, Dopp E, Flemming HC, Wingender J (2011) Influence of copper ions on the viability and cytotoxicity of Pseudomonas aeruginosa under conditions relevant to drinking water environments. Int J Hyg Environ Health 214:485-492

Effendi I, Austin B (1991) Survival of the fish pathogen Aeromonassalmonicida in seawater. FEMS Microbiol Lett 84:103-106

Ensign JC (1970) Long-term starvation survival of rod and spherical cells of Arthrobacter crystallopoietes. J Bacteriol 103:569-577

Evelyn TPT, Bell GR, Prosperi-Porta L, Ketcheson JE (1989) A simple technique for accelerating the growth of the kidney-disease bacterium Renibacterium salmoninarum on a commonly used culture medium (KDM2). Dis Aquat Org 7:231-234 
Fegatella F, Cavicchioli R (2000) Physiological responses to starvation in the marine oligotrophic ultramicrobacterium Sphingomonas sp strain RB2256. Appl Environ Microbiol 66:2037-2044

Fehr A, Walther E, Schmidt-Posthaus H, Nufer L, Wilson A, Svercel M, Richter D, Segner H, Pospischil A, Vaughan L (2013) Candidatus Syngnamydia venezia, a novel member of the phylum Chlamydiae from the broad nosed pipefish, Syngnathus typhle. PLoS ONE 8:e70853

Fera MT, Maugeri TL, Gugliandolo C, La Camera E, Lentini V, Favaloro A, Bonanno D, Carbone M (2008) Induction and resuscitation of viable nonculturable Arcobacter butzleri cells. Appl Environ Microbiol 74:3266-3268

Gample SP, Agrawal S, Sarkar D (2019) Evidence of nitrite acting as a stable and robust inducer of noncultivability in Mycobacterium tuberculosis with physiological relevance. Sci Rep 9:9261

Garcia TM, Jones S, Pelaz C, Millar RD, Kwaik YA (2007) Acanthamoeba polyphaga resuscitates viable non-culturable Legionella pneumophila after disinfection. Environ Microbiol 9:1267-1277

Giagnoni L, Arenella M, Galardi E, Nannipieri P, Renella G (2018) Bacterial culturability and the viable but non-culturable (VBNC) state studied by a proteomic approach using an artificial soil. Soil Biol Biochem 118:51-58

Gourmelon M, Cillard J, Pommepuy M (1994) Visible light damage to Escherichia coli in seawater: oxidative stress hypothesis. J Appl Bacteriol 77:105-112

Guillou S, Leguerinel I, Garrec N, Renard MA, Cappelier JM, Federighi M (2008) Survival of Campylobacter jejuni in mineral bottled water according to difference in mineral content: application of the Weibull model. Water Res 42:2213-2219

Gupte AR, de Rezende CLE, Joseph SW (2003) Induction and resuscitation of viable but nonculturable Salmonella enterica serovar Typhimurium DT104. Appl Environ Microbiol 69:6669-6675

Hahn MW, Koll U, Schmidt J (2019) Isolation and cultivation of bacteria. In: Hurst C (ed) The structure and function of aquatic microbial communities. Advances in Environmental Microbiology, vol 7. Springer, Cham, pp 313-351

Haller CM, Rolleke S, Vybiral D, Witte A, Velimirov B (2000) Investigation of $0.2 \mu \mathrm{m}$ filterable bacteria from the Western Mediterranean Sea using a molecular approach: dominance of potential starvation forms. FEMS Microbiol Ecol 31:153-161

Han D, Zhu L, Cui H-L (2019) Halorussus litoreus sp. nov., isolated from the salted brown alga Laminaria. Int J Syst Evol Microbiol 69:767-772

Handford JI, Ize B, Buchanan G, Butland GP, Greenblatt J, Emili A, Palmer T (2009) Conserved network of proteins essential for bacterial viability. J Bacteriol 191:4732-4749

Hirvela-Koski V, Pohjanvirta T, Koski P, Sukura A (2006) Atypical growth of Renibacterium salmoninarum in subclinical infections. J Fish Dis 29:21-29

Hoff KA (1989) Survival of Vibrio anguillarum and Vibrio salmonicida at different salinities. Appl Environ Microbiol 55:1775-1786

Hommel B, Sturny-Leclere A, Volant S, Veluppillai N (2019) Cryptococcus neoformans resists to drastic conditions by switching to viable but non-culturable cell phenotype. PLoS Pathog 15:e1007945

Hutchison EA, Miller DA, Angert ER (2014) Sporulation in bacteria: beyond the standard model. Microbiol Spectr 2:TBS-0013-2012

Janssen PH (2009) Dormant microbes: scouting ahead or plodding along? Nature 458:831

Jung J-H, Lee J-E (2016) Real-time bacterial microcolony counting using on-chip microscopy. Sci Rep 6:21473

Kan Y, Jiang N, Xu X, Lyu Q, Gopalakrishnan V, Walcott R, Burdman S, Li J, Luo L (2019) Induction and resuscitation of the viable but non-culturable (VBNC) state in Acidovorax citrulli, the causal agent of bacterial fruit blotch of cucurbitaceous crops. Front Microbiol 10:1081
Kana BD, Mizrahi V (2010) Resuscitation-promoting factors as lytic enzymes for bacterial growth and signaling. FEMS Immunol Med Microbiol 58:39-50

Kaprelyants AS, Gottschal JC, Kell DB (1993) Dormancy in non-sporulating bacteria. FEMS Microbiol Lett 104:271-286

Kaprelyants AS, Mukamolova GV, Kell DB (1994) Estimation of dormant Micrococcus luteus cells by penicillin lysis and by resuscitation in cell-free spent culture medium at high dilution. FEMS Microbiol Lett 115:347-352

Keep NH, Ward JM, Cohen-Gonsaud M, Henderson B (2006) Wakeup! Peptidoglycan lysis and bacterial non-growth states. Trends Microbiol 14:271-276

Knobloch S, Johannsson R, Marteinsson VT (2020) Genomic analysis of sponge symbiont 'Candidatus Halichondribacter symbioticus' shows genomic adaptation to a hos-dependent lifestyle. Environ Microbiol 22:483-498

Kogure K, Simidu U, Taga N (1979) A tentative direct microscopic method for counting living marine bacteria. Can J Microbiol 25:415-420

Lewis K, Epstein S, D’Onofrio A, Ling LL (2010) Uncultured microorganisms as a source of secondary metabolites. J Antibiot (Tokyo) 63:468-476

Li Y, Chen J, Zhao M, Yang Z, Yue L, Zhang X-H (2017) Promoting resuscitation of viable but non-culturable cells of Vibrio harveyi by a resuscitation promoting factor-like protein YeaZ. J Appl Microbiol 122:338-346

Liao H, Zhong X, Xu L, Ma Q, Wang Y, Cai Y, Guo X (2019) Quorumsensing systems trigger catalase expression to reverse the oxyR deletion-mediated VBNC state in Salmonella typhimurium. Res Microbiol 170:65-73

Lim A, Eleuterio M, Hutter B, Murugasu-Oei B, Dick T (1999) Oxygen depletion-induced dormancy in Mycobacterium bovis BCG. J Bacteriol 181:2252-2256

Liu Y, Wang C, Tyrrell G, Hrudey SE, Li XF (2009) Induction of Escherichia coli $\mathrm{O} 157: \mathrm{H} 7$ into the viable but non-culturable state by chloraminated water and river water, and subsequent resuscitation. Environ Microbiol Rep 1:155-161

Liu J, Deng Y, Soteyome T, Li Y, Su J, Li L, Li B, Shirtliff ME, Xu Z, Peters BM (2018) Induction and recovery of the viable but nonculturable state of Hop-Resistance Lactobacillus brevis. Front Microbiol 9:2076

Lleo MM, Tafi MC, Canepari P (1998) Nonculturable Enterococcus faecalis cells are metabolically active and capable of resuming active growth. Syst Appl Microbiol 21:333-339

Lleo MM, Bonato B, Tafi MC, Signoretto C, Boaretti M, Canepari P (2001) Resuscitation rate in different enterococcal species in the viable but non-culturable state. J Appl Microbiol 91:1095-1102

Locey KJ, Lennon JT (2016) Scaling laws predict global microbial diversity. Proc Natl Acad Sci USA 113:5970-5975

Luo D, Chen J, Xie G, Yue L, Wang Y (2019) Enzyme characterization and biological activities of a resuscitation promoting factor from an oil degrading bacterium Rhodococcus erythropolis KB1. PeerJ 7:148-160

Maalej S, Gdoura R, Dukan S, Hammami A, Bouain A (2004) Maintenance of pathogenicity during entry into and resuscitation from viable but nonculturable state in Aeromonas hydrophila exposed to natural seawater at low temperature. J Appl Microbiol 97:557-565

McIntosh D, Austin D (1990) Recovery of cell-wall deficient forms (L-forms) of the fish pathogens Aeromonas salmonicida and Yersinia ruckeri. Syst Appl Microbiol 13:378-381

Mesrop A, Williams TC, Oliver JD (2014) Interspecific quorum sensing mediates the resuscitation of viable but nonculturable vibrios. Appl Environ Microbiol 80:2478-2483

Misra R, Hoefman S, Van Hoorde K, Boon N, Vandamme P, De Vos P, Heylen K (2012) Survival or revival: Long-term preservation 
induces a reversible viable but non-culturable state in methaneoxidizing bacteria. PLoS ONE 7:e34196

Morishige Y, Fujimori K, Amano F (2013) Differential resuscitative effect of pyruvate and its analogues on VBNC (viable but nonculturable) Salmonella. Microbes Environ 28:180-186

Mu D-S, Liang Q-Y, Wang X-M, Lu D-C, Shi M-J, Chen G-J, Du Z-J (2018) Metatranscriptomic and comparative genomic insights into resuscitation mechanisms during enrichment culturing. Microbiome 6:230

Mukamolova GV, Yanopolskaya ND, Kell DB, Kaprelyants AS (1998) On resuscitation from the dormant state of Micrococcus luteus. Antonie von Leeuwenhoek 73:237-243

Mukamolova GV, Turapov OA, Kazaryan K, Telkov M, Kaprelyants AS, Kell DB, Young M (2002) The rpf gene of Micrococcus luteus encodes an essential secreted growth factor. Mol Microbiol 46:611-621

Mukhanov VS, Rylkova OA, Sakhon EG, Butina TV, Belykh OI (2016) Transbiome invasions of femtoplankton. Contemp Probl Ecol 9:266-271

Munn CB (2020) Marine microbiology: ecology and application, 3rd edn. CRC Press, Boca Raton, p 95

Nakashima T, Muraoka W, Takeshita S (2007) A selective separation for slower-growing bacteria from marine soils. Instrum Sci Technol 35:211-217

Nikitushkin VD, Demina GR, Shleeva MO, Kaprelyants AS (2012) Peptidoglycan fragments stimulate resuscitation of "nonculturable" mycobacteria. Antonie von Leeuwenhoek 103:37-46

Obayashi Y, Suzuki S (2019) High growth potential of transiently $0.2 \mu \mathrm{m}$-filterable bacteria with extracellular protease activity in coastal seawater. Plankton Benthos Res 14:276-286

Oliver JD (2005) The viable but nonculturable state in bacteria. J Microbiol 43:93-100

Oliver JD (2010) Recent findings on the viable but nonculturable state in pathogenic bacteria. FEMS Microbiol Rev 34:415-425

Oliver JD (2016) The viable but nonculturable state for bacteria: status update. Microbe 11:159-164

Oliver JD, Bockian R (1995) In vivo resuscitation, and virulence towards mice, of viable but nonculturable cells of Vibrio vulnificus. Appl Environ Microbiol 61:2620-2623

Oliver JD, Hite F, McDougald D, Andon NL, Simpson LM (1995) Entry into, and resuscitation from, the viable but nonculturable state by Vibrio vulnificus in an estuarine environment. Appl Environ Microbiol 61:2624-2630

Olson BH (1978) Enhanced accuracy of coliform testing in seawater by a modification of most-probable-number method. Appl Environ Microbiol 36:438-444

Oruno M, Parada C, Ogayar E, Kaberdin VR, Arana I (2019) Effects of abiotic and biotic factors on Vibrio harveyi ATCC $14126^{\mathrm{T}}$ survival dynamics in seawater microcosms. Aquat Microb Ecol 83:109-118

Ozkanca R, Saribiyik F, Isik K, Sahin N, Kariptas E, Flint KP (2009) Resuscitation and quantification of stressed Escherichia coli $\mathrm{K} 12$ NCTC8797 in water samples. Microbiol Res 164:212-220

Panutdaporn N, Kawamoto K, Asakura H, Makino SI (2006) Resuscitation of the viable but non-culturable state of Salmonella enterica serovar Oranienburg by recombinant resuscitation-promoting factor derived from Salmonella Typhimurium strain LT2. Int J Food Microbiol 106:241-247

Papenfort K, Bassler BL (2016) Quorum sensing signal-response systems in Gram-negative bacteria. Nat Rev Microbiol 14:576-588

Pasquaroli S, Zandri G, Vignaroli C, Vuotto C, Donelli G, Biavasco F (2013) Antibiotic pressure can induce the viable but non-culturable state in Staphylococcus aureus growing in biofilms. J Antimicrob Chemother 68:1812-1817

Pinto D, Almeida V, Almeida Santos M, Chambel L (2011) Resuscitation of Escherichia coli VBNC cells depends on a variety of environmental or chemical stimuli. J Appl Microbiol 110:1601-1611

Pinto D, Santos MA, Chambel L (2015) Thirty years of viable but nonculturable state research: unsolved molecular mechanisms. Crit Rev Microbiol 41:61-76

Rahman M, Abd H, Romling U, Sandstrom G, Mollby R (2008) Aeromonas-Acanthamoeba interaction and early shift to a viable but nonculturable state of Aeromonas by Acanthamoeba. J Appl Microbiol 104:1449-1457

Rappe MS, Giovannoni SJ (2003) The uncultured microbial majority. Ann Rev Microbiol 57:369-394

Rolfe MD, Rice CJ, Lucchini S, Pin C, Thompson A, Cameron ADS, Alston M, Stringer MF, Betts RP, Baranyi J, Peck MW, Hinton JCD (2012) Lag phase is a distinct growth phase that prepares bacteria for exponential growth and involves transient metal accumulation. J Bacteriol 194:686-701

Roszak DB, Colwell RR (1987) Survival strategies of bacteria in the natural environment. Microbiol Rev 51:365-379

Salma M, Rousseaux S, Sequeira-Le Grand A, Divol B, Alexandre H (2013) Characterization of the viable but nonculturable (VBNC) state in Saccharomyces cerevisiae. PLoS ONE 8:e77600

Schut F, Devries EJ, Gottschal JC, Robertson BR, Harder W, Prins RA, Button DK (1993) Isolation of typical marine-bacteria by dilution culture - growth, maintenance, and characteristics of isolates under laboratory conditions. Appl Environ Microbiol 59:2150-2160

Showalter GM, Deming JW (2018) Low-temperature chemotaxis, halotaxis and chemohalotaxis by the psychrophilic marine bacterium Colwellia psychrerythraea 34H. Environ Microbiol Rep 10:92-101

Smith JJ, Howington JP, McFeters GA (1994) Survival, physiological response and recovery of enteric bacteria exposed to a polar marine environment. Appl Environ Microbiol 60:2977-2984

Steinert M, Emody L, Amann R, Hacker J (1997) Resuscitation of viable but nonculturable Legionella pneumophila Philadelphia JR32 by Acanthamoeba castellanii. Appl Environ Microb 63:2047-2053

Su X, Shen X, Ding L, Yokota A (2011) Study on the flocculability of the Arthrobacter sp., an actinomycete resuscitated from the VBNC state. World J Microbiol Biotechnol 28:91-97

Su X, Shen H, Yao X, Ding L, Yu C, Shen C (2013) A novel approach to stimulate the biphenyl-degrading potential of bacterial community from PCBs-contaminated soil of e-waste recycling sites. Bioresour Technol 146:27-34

Su X, Sun F, Wang Y, Hashmi MZ, Guo L, Ding L, Shen C (2015) Identification, characterization and molecular analysis of the viable but nonculturable Rhodococcus biphenylivorans. Sci Rep 5:18590

Su X, Zhang S, Mei R, Zhang Y, Hashmi MZ, Liu J, Lin H, Ding L, Sun F (2018) Resuscitation of viable but non-culturable bacteria to enhance the cellulose-degrading capability of bacterial community in composting. Microb Biotechnol 11:527-536

Sun F, Chen J, Zhong L, Zhang X-H, Wang R, Guo Q, Dong Y (2008) Characterization and virulence retention of viable but nonculturable Vibrio harveyi. FEMS Microbiol Ecol 64:37-44

Sussman M, Loya Y, Fine M, Rosenberg E (2003) The marine fireworm Hermodice carunculata is a winter reservoir and spring-summer vector for the coral-bleaching pathogen Vibrio shiloi. Environ Microbiol 5:250-255

Takayanagi A, Takahashi S, Nishida H (2016) Requirement of dark culture condition for enlargement of spheroplasts of the aerobic anoxygenic photosynthetic marine bacterium Erythrobacter litoralis. J Gen Appl Microbiol 62:14-17

Torrella F, Morita RY (1981) Microcultural study of bacterial size changes and microcolony and ultramicrocolony formation by 
heterotrophic bacteria in seawater. Appl Environ Microbiol 41:518-527

Trainor VC, Udy RK, Bremer P, Cook GM (1999) Survival of Streptococcus pyogenes under stress and starvation. FEMS Microbiol Lett 76:421-428

Trevors JT (2011) Viable but non-culturable (VBNC) bacteria: gene expression in planktonic and biofilm cells. J Microbiol Methods 86:266-273

Vilhena C, Kaganovitch E, Grunberger A, Motz M, Forne I, Kohlheyer D, Jung K (2019) Importance of pyruvate sensing and transport for the resuscitation of viable but nonculturable Escherichia coli K-12. J Bacteriol 201:e00610-18

Volpi M, Lomstein BA, Sichert A, Roy H, Jorgensen BB, Kjeldsen KU (2017) Identity, abundance and reactivation kinetics of thermophilic fermentative endospores in cold marine sediment and seawater. Front Microbiol 8:131

Vybiral D, Denner EBM, Haller CM, Busse HJ, Witte A, Hofle MG, Velimirov B (1999) Polyphasic classification of $0.2 \mu \mathrm{m}$ filterable bacteria from the western Mediterranean Sea. Syst Appl Microbiol 22:635-646

Willenburg E, Divol B (2012) Quantitative PCR: An appropriate tool to detect viable but not culturable Brettanomyces bruxellensis in wine. Int J Food Microbiol 160:131-136
Wong HC, Wang PL, Chen SY, Chiu SW (2004) Resuscitation of viable but non-culturable Vibrio parahaemolyticus in a minimum salt medium. FEMS Microbiol Lett 233:269-275

Wormer L, Hoshino T, Bowles MW, Viehweger B, Adhikari RR, Xiao N, Uramoto G, Konneke M, Lazar CS, Morono Y, Inagaki F, Hinrichs KU (2019) Microbial dormancy in the marine subsurface: Global endospore abundance and response to burial. Sci Adv 5:eaav 1024

Xu H-S, Roberts N, Singleton FL, Attwell RW, Grimes DJ, Colwell RR (1982) Survival and viability of nonculturable Escherichia coli and Vibrio cholerae in the estuarine and marine environment. Microb Ecol 8:313-323

Zeng B, Zhao G, Cao X, Yang Z, Wang C, Hou L (2013) Formation and resuscitation of viable but nonculturable Salmonella typhi. Biomed Res Int 2013:907170

Zhong L, Chen J, Zhang X-H, Jiang Y (2009) Entry of Vibrio cincinnatiensis into viable but nonculturable state and its resuscitation. Lett Appl Microbiol 48:247-252

Zhong QP, Tian J, Wang B, Wang L (2016) PMA based real-time fluorescent LAMP for detection of Vibrio parahaemolyticus in viable but nonculturable state. Food Control 63:230-238 